http://dx.doi.org/10.18232/alhe.979

Artículos

\title{
O subemprego em perspectiva histórica e a estrutura de ocupações no Brasil entre 1980 e 2010
}

\section{Underemployment in Historical Perspective and the Brazilian Occupational Structure between 1980 and 2010}

Gustavo Zullo ${ }^{1} *$ (DD 0000-0002-7476-5976

${ }^{1}$ Universidade Estadual de Campinas, Instituto de Economia, São Paulo, Brasil.

*Correspondencia: gustavozullo@gmail.com

Resumo. Este artigo propõe um exame teórico e histórico das fragilidades que atravessam a estrutura ocupacional brasileira a partir do conceito de subemprego apresentada por Rodríguez (1985). De modo a destacar os vínculos entre as atividades agrícolas e não-agrícolas, observamos uma deterioração acentuada do mercado de trabalho entre 1980 e 2010 . Este período é, de um lado, marcado pela desindustrialização e, de outro, pela especialização regressiva, que tem na expansão constante da fronteira agrícola uma de suas principais características.

Palabras clave: história; subdesenvolvimento; estrutura ocupacional; subemprego.

Abstract. This paper proposes a theoretical and historical examination of the weaknesses that cross the Brazilian occupational structure from the concept of underemployment developed by Rodríguez (1985). In order to highlight the links between agricultural and non-agricultural activities, we observed a marked deterioration of the labour market between 1980 and 2010. This period is, on the one hand, characterized by deindustrialization and, on the other hand, by regressive specialization that has in the constant expansion of agricultural frontier one of its main characteristics.

CÓMO CITAR: Zullo, G. (2019). O subemprego em perspectiva histórica e a estrutura de ocupações no Brasil entre 1980 e 2010. America Latina en la Historia Económica, 26(3), e979. DOI: 10.18232/alhe.979 
Key words: History; underdevelopment; occupational structure; underemployment.

JEL: J21; N01; N360.

Recibido: 29 de Março de 2018.

Aceptado: 28 de Maio de 2018.

Publicado: 17 de Maio de 2019.

Corpo colaborador: Coordenação de Aperfeiçoamento de Pessoal de Nível Superior (Capes), Brasil.

\section{INTRODUÇÃO}

O nosso principal objetivo é apresentar a dinâmica das estruturas do mercado de trabalho brasileiro entre 1980 e 2010 a partir do conceito de subemprego apresentado por Rodríguez (1985).1 Para tanto, nosso trabalho articula duas dimensões complementares, de um lado, apontamos uma histórica da economia brasileira, centrada nas relações entre o mercado interno e a estrutura produtiva e, de outro lado, apresentamos uma análise qualitativa do mercado de trabalho brasileiro com base em dados extraídos dos censos demográficos, sendo que esta parte é acompanhada de uma explicação metodológica.

Primeiramente, destacamos aspectos históricos importantes para se compreender a erosão da estrutura produtiva brasileira e da estrutura de ocupações, que atualmente é penalizada por uma desindustrialização aliada de uma especialização regressiva ${ }_{2}^{2}$ Embora a financeirização e o neoliberalismo sejam fundamentais para se compreender os espaços que se fecharam à política econômica, como normalmente é destacado na literatura econômica, destacaremos aqui os nexos internos da estrutura da economia brasileira que contribuíram para a consolidação do mercado de trabalho tal como ele se apresenta atualmente. Nesse sentido, estabeleceremos algumas relações entre a industrialização dependente, a expansão da empresa agromercantil e a formação de um mercado interno incapaz de sustentar um processo de desenvolvimento nacional ${ }^{3}$-nas palavras de Furtado (1972, pp. 65-66), a economia brasileira não criou mecanismos que pudessem formar um anel de feed-back.

As deformações típicas de uma estrutura produtiva subdesenvolvida, que se singulariza pela heterogeneidade, preservaram uma grande quantidade de ocupações de baixa produtividade em variados setores da economia, como na construção civil e na agricultura de subsistência. Assim, a estrutura ocupacional brasileira se modernizou sem perder o que possuía de mais arcaico, que é precisamente a existência de uma grande massa de atividades de baixa produtividade que estão disseminadas tanto nos setores secundário e terciário como no setor agrícola, que ainda se configura como um reservatório de mão de obra para as atividades não-agrícolas.

\footnotetext{
${ }^{1}$ Esta posição deriva diretamente da interpretação de Pinto (1976) sobre a heterogeneidade estrutural, que se revela a partir da identificação de diferentes produtividades do trabalho na estrutura produtiva.

${ }^{2}$ Para a definição original de especialização regressiva, ver Coutinho (1997). Para uma análise da desindustrialização a partir da perspectiva da formação nacional, ver Espósito (2016).

${ }^{3}$ Segundo Furtado (1980), o desenvolvimento nacional é definido pela integração do sistema produtivo, a integração social e a integração regional de um país, para o que o desenvolvimento das forças produtivas é apenas um meio. De tal modo, entende-se que expansão econômica deve articular a acumulação de capital, a produção e a geração de um fluxo de demanda com a criação dos meios científicos e tecnológicos necessários ao processo. Caso contrário, a acumulação de capital ocorrerá apenas no nível dos bens finais de consumo.
} 
Embora estes não sejam elementos novos na análise da economia brasileira, os mesmos costumam ser negligenciados nas análises sobre a evolução do mercado de trabalho e da economia brasileira na década de 2000. As análises sobre este período, comumente celebrado pelas suas melhorias conjunturais, como o foram o aumento da formalização das relações de trabalho e a elevação real do salário mínimo ${ }^{4}$ não destacam com a devida atenção a possibilidade aberta de reversão desses processos ${ }^{5}$ Sem a exata noção de que a superação substantiva da precariedade do mercado de trabalho requer a superação de entraves estruturais de nossa economia, a explicação da rapidez com que esses mesmos avanços refluem desde 2015 tende a ser resumida a erros de política econômica. Tal tratamento esvazia a natureza do problema, que não se resume a questões de política econômica nem a determinações domésticas -caso contrário, como explicar o atual retrocesso econômico e social que se alastra não só a países subdesenvolvidos como também a países desenvolvidos?

Em segundo lugar, nossa análise da estrutura ocupacional no período 1980-2010 destaca a relação entre as atividades agrícolas e não-agrícolas. Neste sentido, é importante também destacar que a metodologia de que nos valemos, desenvolvida por Rodríguez (1985), articula a estrutura e a dinâmica das ocupações agrícolas e não-agrícolas através da ideia de subemprego, que é definida, basicamente, a partir da baixa produtividade do trabalho de uma determinada atividade econômica $\rfloor^{6}$

Para evidenciar nossa contribuição ao debate sobre a deterioração do mercado de trabalho brasileiro, este artigo contém, além desta introdução, outras duas seções mais as considerações finais. Na primeira seção, apresentamos uma interpretação sobre a formação econômica brasileira com o intuito de lançar luz sobre as limitações que a expansão da lavoura agromercantil impôs à industrialização por substituição de importações. Depois, analisamos o mercado de trabalho dentro de uma perspectiva de longo prazo a partir do conceito de subemprego formulado por Rodríguez (1985), destacando o período que vai de 1980 a 2010. Além disso, esta última seção apresenta sucintamente a metodologia utilizada, cujos critérios divergem consideravelmente dos critérios que balizam a metodologia tradicional, baseada na dicotomia entre empregos formais e informais.

\section{INDUSTRIALIZAÇÃO DEPENDENTE E EMPRESA AGROMERCANTIL}

A despeito de uma complexa estrutura industrial construída em meados do século xx, a economia brasileira elevou os seus graus de heterogeneidade. Antes de estabelecer os nexos entre produção e consumo que associariam a acumulação de capital ao atendimento das necessidades da maior parte de sua população, o padrão de acumulação praticado no Brasil preservou um baixíssimo nível tradicional de vida mesmo nos períodos de crescimento mais intenso do mercado interno. Na medida em que a demanda se entrava constantemente abaixo do seu potencial, preservando o país sob uma baixa renda per capita, como Celso Furtado salientou incontáveis vezes, bloqueou-se os canais pelos quais se poderia construir um crescimento auto-sustentado.

\footnotetext{
${ }^{4}$ Para um exame que avalia os índices de formalização e da valorização do salário mínimo, ver Baltar (2015).

${ }^{5}$ Neste artigo, os processos de regressão são compreendidos como uma reversão neocolonial (Sampaio Jr., 2007).

${ }^{6}$ Para maiores detalhes sobre a metodologia utilizada no trabalho seminal de Rodríguez (1985), ver Portugal Jr. (1998, 2012). Além disso, a definição de subemprego será melhor trabalhada no decorrer deste trabalho.
} 
Todavia, a análise dos nexos precários entre produção e consumo ganha maior inteligibilidade quando se apresenta algumas características da atuação das burguesias brasileiras e do capital externo no processo brasileiro de industrialização por substituição de importações, o qual se passou, em linhas gerais, entre 1930 e 1980.

Em meados do século passado, aproveitando-se de conjunturas internacionais em que se afrouxou o controle sobre as economias primário-exportadoras, emergiram estratégias para a superação de barreiras externas à acumulação de capital. Durante a segunda guerra mundial, por exemplo, uma parcela da burguesia se aproveitou para diversificar a estrutura industrial como estratégia para se mitigar o estrangulamento cambial e financeiro -mais precisamente, deu-se início à primeira fase da industrialização por substituição de importações, que usualmente é datada entre 1930 e 19567 Todavia, este impulso à atividade industrial no Brasil não se constituiu única e exclusivamente como uma investida de um demiúrgico capital nacional. Ainda que parte da burguesia brasileira tenha participado ativamente dos primeiros e fundamentais passos na construção de um sistema econômico, sobretudo na formação dos setores de bens intermediários, a participação do capital internacional na produção de produtos finais acentuou-se a partir da década de 1950. Este momento representou o início de uma nova etapa da dependência externa, caracterizada por um controle direto da produção, que se expressou na abertura de inúmeras filiais 8 Com o fito de avançar sobre a conquista de nosso espaço econômico, estes capitais expandiram seu domínio a todo empreendimento que lhes pudesse render lucro, sobretudo nos "postos-chave e de significação econômica decisiva” (Prado Jr., 2012, p. 323), o que se fazia sem maiores comprometimentos com o desenvolvimento nacional 9

De tal modo, a atuação do capital internacional nos mercados periféricos obedecia a dois princípios norteadores. Em primeiro lugar, a sua contribuição para o desenvolvimento capitalista em alguns poucos países selecionados era parte de sua política de combate ao comunismo, que àquela época ameaçava a hegemonia do capitalismo como modelo de organização sociocultural, econômica e política. Por outro lado, a abertura de filiais das grandes empresas financeiras e nãofinanceiras garantia o controle direto sobre a industrialização periférica. Neste novo modelo de dominação externa, portanto, o capital internacional passou a possuir uma outra estratégia de intervenção. Ao invés de imposições comerciais, como atuara até então, passou a fixar desde dentro das fronteiras nacionais as normas, o ritmo e os limites do desenvolvimento capitalista, os quais eram determinados pelas divisas obtidas através do endividamento externo e dos saldos exportadores dos setores primários. Disso, nota-se que a modernização acelerada da economia brasileira se desenrolou sem que fossem superadas algumas das características de uma economia tipicamente colonial, como a elevada concentração fundiária e a dependência dos setores primários para a obtenção de divisas. Sem autonomia financeira e tecnológica, o processo substitutivo não adquiriu, nem mesmo sob o impulso do II Plano Nacional de Desenvolvimento (II PND), condições para projetar com força a sua estrutura urbano-industrial sobre o mercado externo, evidenciando a

\footnotetext{
${ }^{7} \mathrm{~A}$ despeito de discordâncias com Draibe (1985) quanto à potência da burguesia -ao menos de parte importante dela-, a autora aponta para algumas informações interessantes sobre a participação do Estado brasileiro na expansão industrial.

${ }^{8}$ Segundo Caio Prado Jr. (1987, p. 88), a instalação de subsidiárias e de empresas associadas ao capital internacional representaram cerca de $40 \%$ da abertura de empreendimentos industriais.

${ }^{9}$ Para uma opinião diferente da que apresentamos, ver Tavares (1981, p. 41).
} 
acomodação entre os interesses externos e os interesses das camadas mais tradicionais da burguesia brasileira -essa relação entre os interesses externos e internos foi denominada por Florestan Fernandes (2006) como uma dupla articulação.

Conservada a primazia exportadora da empresa agromercantil, que no seu processo de expansão expulsava grande quantidade de trabalhadores para os centros urbanos, garantia-se que o consumo dos bens de consumo durável fossem um privilégio dos ricos e da pequena classe média. De outro modo, a urbanização baseada na absorção de milhares de trabalhadores rurais que não foram absorvidos pela indústria nem pelos serviços modernos induziu a formação de uma economia de baixos salários, o que limitava o tamanho do mercado consumidor e da produção nacional. Assim, a expansão da indústria possuía um limite intrínseco, pois ao mesmo tempo em que a estratégia de desenvolvimento urbano-industrial estava dependia no crescimento do mercado interno, o mesmo se encontrava limitado por uma brutal concentração da renda. Não foi por outra razão que Caio Prado Jr. (1987) afirmara que "o progresso material se anula em boa parte e se auto-limita, encerrando-se em estreitas perspectivas" (pp. 91-92). De tal modo, observa-se que não estava no horizonte do processo substitutivo a integração da economia nem da sociedade, o que se expressava sobre os milhões de trabalhadores marginalizados 10 Concorria-se para que, em conjunturas desfavoráveis, os investimentos se retraíssem sem que o mercado interno pudesse funcionar como um retaguarda segura. Frágil, o modelo brasileiro não estabeleceu os nexos entre produção e consumo que seriam tão necessários para que a industrialização adquirisse autonomia, o que significa que a modernização da economia seria necessariamente acompanhada pela preservação de elevadas taxas de subemprego.

Esta nova forma de intervir nas economias periféricas, parte intrínseca daquele que era o tempo histórico do imperialismo total ${ }^{11}$ contribuiu para aprofundar a heterogeneidade estrutural no país. Não apenas a construção de um sistema econômico como um conjunto harmonicamente encadeado continuou paralisada como também as ocupações de maior produtividade do trabalho ficaram restritas a poucos setores e ramos de atividade, o que acirrou a dispersão das rendas do trabalho no país. Na medida em que o processo substitutivo avançava, assim como também avançavam as lavouras comerciais sobre as roças de subsistência, expulsando quantidade expressiva de trabalhadores rurais para os centros urbanos, a remuneração das ocupações agrícolas e das ocupações não-agrícolas menos valorizadas não encontravam condições para crescer. A massa de trabalhadores urbanos ocupados em atividades de baixa produtividade, alimentada fundamentalmente pelo êxodo rural, constituiu-se em uma formidável ferramenta para preservar rebaixados os seu custos salariais, assim como as péssimas condições de trabalho e remuneração do trabalhador rural minavam o poder de barganha do trabalhador urbano. Segundo Prado Jr. (1987)

\footnotetext{
${ }^{10} \mathrm{O}$ processo que produz esses subempregados pode ser identificado como o processo de marginalização social tal como entendido por Kowarick (1975). Ambas as categorias -subemprego e marginalidade social- estão baseadas na identificação de massas trabalhadoras desocupadas ou ocupadas em atividades de baixa produtividade do trabalho por longos períodos de tempo. Para uma análise do processo de marginalização como o processo que reproduz o subemprego, ver Zullo (2017).

${ }^{11}$ Segundo Fernandes (2009), o imperialismo total consistiria na "dominação externa a partir de dentro em todos os níveis da ordem social, desde o controle da natalidade, a comunicação e consumo de massa, até a educação, a transplantação maciça de tecnologia ou de instituições sociais, a modernização da infra e da superestrutura, os expedientes financeiros ou do capital, o eixo vital da política nacional, etc." (p. 27).
} 
o que associa de maneira mais íntima trabalhadores da cidade e do campo é a circunstância de que a solução dos problemas essenciais de todos e o atendimento de suas reivindicações se confundem afinal num mesmo processo, que se pode comparar à tendência ao nivelamento dos líquidos em vasos comunicantes. Se as melhores condições de trabalho e emprego nos centros urbanos constituem, pela concorrência que determinam no mercado comum de mão de obra, a principal, senão única circunstância capaz de elevar o poder de barganha dos trabalhadores rurais, doutro lado os baixos padrões dominantes no campo constituem dos principais fatores de depressão dos salários e agravamento das condições de emprego do trabalhador urbano. A massa trabalhadora rural se apresenta no Brasil como uma reserva permanente de mão de obra pouco exigente, sempre disposta a afluir para a cidade e aí se oferecer em condições mais favoráveis para os empregadores. Concorre assim muito seriamente com o trabalhador urbano, e tende por isso a lhe neutralizar as exigências (p. 173).

As mudanças por que passava o mercado de trabalho devem ser compreendidas, portanto, à luz das transformações que se passaram no campo em articulação ao que se passava nos centros urbanos do país. A expansão da fronteira agrícola, amparada pelo Estado e fundamentada na concentração fundiária (Oliveira, 2003; Szmrecsányi 1982), continuamente alimentou a demanda de trabalho nas atividades não-agrícolas, onde a precariedade das condições de vida e trabalho era, sob outras formas, análoga à do campo. A conexão entre os trabalhadores urbanos e os trabalhadores rurais, assim como entre as suas respectivas condições de trabalho, conectou e estabeleceu o campo e a cidade como uma unidade que determinou a taxa de salários de toda a economia.

A rigidez da estrutura social foi um elemento essencial, portanto, para definir o alcance da industrialização por substituição de importações. Em momento algum o processo substitutivo se constituiu como "um processo contínuo e autoestimulante, alimentando-se de suas próprias forças e propagando-se por elas" (Prado Jr., 2012, p. 332), que é uma das principais características de um processo de industrialização autônomo. Fundamentalmente direcionada para suprir a demanda final de uma pequena parcela da população, não se constituiu no Brasil mais do que uma estrutura produtiva fragmentada, sobretudo porque não se adquiriu autonomia tecnológica nem se conseguiu avançar satisfatoriamente no setor de bens capital. Nem mesmo a grande expansão da produção de bens duráveis, na década de 1970, que de fato aliviou a pressão sobre as contas externas, foi capaz de extrapolar as fronteiras do país e de transformar a indústria brasileira em uma plataforma de exportações. Afinal, o investimento direto externo foi baseado na instalação de máquinas e equipamentos já completamente amortizados e defasados, pois, em relação às máquinas e equipamentos que as mesmas empresas usavam nos países industrializados (Furtado, 1980).

Prado Jr. (2012, pp. 323-324) chegou mesmo a afirmar que o desenvolvimento econômico no Brasil se assemelhou mais a um breve surto de atividades econômicas condicionado por uma conjuntura internacional excepcional do que a um genuíno processo de desenvolvimento nacional -e aqui é importante destacar que o autor tinha em mente um processo histórico de longa duração, e não os tempos mais curtos das conjunturas econômicas que podem durar algumas décadas. A despeito de todo o esforço industrial, o que se verificou no mais das vezes foi uma substituição de bens de consumo durável que dependia das relações estabelecidas pelas matrizes para que as filiais se abastecessem de insumos 12 Nesse sentido, a estrutura industrial no Brasil deixou de adquirir a

\footnotetext{
${ }^{12} \mathrm{Na}$ mesma linha, Hobsbawm (1995, pp. 273-274) afirmara que o comércio internacional é, em grande medida, determinado pelo comércio intra-firmas.
} 
conexão que caracteriza as industrializações que ocorreram com grau elevado de autonomia. Ao longo de todo o período, o desenvolvimento das forças produtivas no país constituiu-se basicamente da instalação de elos de cadeias produtivas que permitiram um melhor aproveitamento da exploração dos mercados locais na medida em que se reduziram custos trabalhistas, alfandegários e outros custos relativos ao transporte. Parte substantiva do excedente que se produziu foi desviada para a acumulação ao nível dos bens finais de consumo sem que ao menos fosse perseguida uma articulação mais coerente entre essas mesmas atividades industriais 13 -Furtado $(1972$, p. 81) sintetizou este fenômeno como o de uma modernização dos padrões de consumo.

Em suma, a industrialização dependente preservou uma enorme superpopulação relativa. De um lado, o controle externo preservou o subdesenvolvimento da estrutura produtiva. De outro, a atuação da burguesia brasileira na definição da política econômica garantiu-lhe acesso privilegiado ao excedente produzido internamente, o que, naquele contexto de intenso êxodo rural, significou a preservação de um sem-número de subempregados.

\section{Mercado de TRABALHo}

Nesta seção, portanto, daremos continuidade à análise precedente, que nos serve como um referencial teórico e histórico para o exame da dinâmica da economia brasileira entre 1980 e 2010 a partir da análise do mercado de trabalho baseada no conceito de subemprego. Esta passagem, no entanto, não pode ser realizada sem maiores mediações, o que ocorre por duas razões. Primeiramente, entendemos que o significado que normalmente é atribuído ao termo subemprego é diferente daquele que pretendemos transmitir, o que exige uma breve nota. Por sua vez, a análise empírica não pode transcorrer sem uma apresentação sucinta dos critérios que compõem a metodologia de Rodríguez (1985), dado que são muito poucos os trabalhos publicados que a utilizaram.

\section{Definição histórica de subemprego e dinâmica da economia brasileira (1980-2010)}

A primeira formulação de subemprego como categoria analítica foi elaborada por Robinson (1937) no contexto da Grande Recessão, quando o desemprego nas economias centrais disparou. Para ela, este seria um sintoma de estagnação econômica por que os países desenvolvidos atravessavam, sendo que a sua superação deveria ser perseguida pelo Estado através de políticas que estimulassem a demanda efetiva com vistas ao pleno emprego. Assim, seriam criadas novas vagas ao mesmo tempo em que se desenvolveriam mecanismos que estimulassem um melhor aproveitamento daquelas já existentes, o que elevaria a massa de salários e estimularia, pois, o crescimento econômico. De outro modo, as políticas em questão deveriam não só reduzir o desemprego aberto como também deveriam estimular o aumento de produtividade de atividades que se caracterizava com formas disfarçadas de desemprego, que foram caracterizadas por Robinson (1937) como subempregos.

Todavia, um país como o Brasil nunca possuiu condições técnicas, financeiras e político-sociais que permitissem trazer a patamares residuais tanto o nível quanto a participação das ocupações de baixa produtividade. Mesmo no auge do processo substitutivo não se internalizou o controle sobre o progresso técnico nem se transformou as indústrias de alta intensidade de capital em plataforma

${ }^{13}$ Sob vários aspectos, esta posição se assemelha à de Pinto (1976). 
de exportação de produtos ${ }^{14}$ sendo que os setores primários preservaram participação considerável na pauta de exportações, o que preservou a ampliação da fronteira agrícola. De outro modo, o que se diz aqui é que a estrutura produtiva brasileira, apesar de propiciar uma elevação significativa da participação de ocupações de elevada produtividade do trabalho, houve um acréscimo não desprezível do número de subempregados ao longo de todo o processo de modernização. De tal modo, o subemprego não apenas não foi superado como, na verdade, se prolongado no tempo como um fenômeno normal, o que evidenciaria uma distância enorme entre a realidade dos países desenvolvidos, possuidores de uma estrutura industrial relativamente autônoma e fortemente encadeada, e a realidade dos países latino-americanos (Hobsbawm, 1969). Nas formações periféricas, portanto, as atividades de baixa produtividade não expressam períodos de estagnação, como sucedeu na Europa Ocidental e nos Estados Unidos, nos anos 1930. Embora a industrialização tenha sido intensa nos países latino-americanos, sobretudo no Brasil, a elevada proporção de subempregados que persistiu ao processo substitutivo não autorizaria que a sua existência fosse confundida com um fenômeno transitório ${ }^{15}$ Na periferia, parte muito grande dos subempregados e dos desempregados nunca foi considerada uma reserva de trabalho em potencial pelas atividades de alta produtividade. Aqui, boa parte da mão de obra subempregada nunca esteve ocupada em uma atividade de produtividade mais elevada, o que desautorizaria qualquer opinião que confunda o subemprego como um desemprego disfarçado. Para uma massa enorme de trabalhadores, a ideia de retorno a uma atividade de elevada produtividade do trabalho -o que daqui em diante identificaremos simplesmente como emprego- nunca existiu. A industrialização dependente não apenas preservou a heterogeneidade da estrutura produtiva como tampouco incorporou a massa da população trabalhadora como consumidora dos bens finais mais sofisticados (Furtado, 1972, pp. 51-52). A despeito da participação do subemprego na população ocupada ter caído significativamente, o seu nível absoluto continuou e ainda continua bastante elevado, o que representa, por si só, um agravamento das possibilidades de homogeneização da estrutura ocupacional no Brasil.

O subdesenvolvimento não foi subvertido pela introdução e expansão da moderna indústria. Embora as forças produtivas tenham crescido de modo significativo, o seu potencial foi limitado pela preservação de uma grande população ocupada em atividades de baixa produtividade e que pagam baixos salários ${ }^{16}$ como já salientamos acima. De outro modo, a reprodução em escala ampliada do subemprego, que reduzia o potencial da demanda, impediu uma dinamização mais intensa da economia. A não-incorporação de parte importante da população às atividades modernas inviabilizou qualquer movimento de homogeneização social, o que significa que boa parte desta mesma população continuou socialmente segregada dos meios de classificação e valorização social, como é o acesso a uma ocupação de média ou alta produtividade. Mesmo no período mais sólido de progresso material no país, que na nossa avaliação é capturado pelos dados referentes ao

\footnotetext{
${ }^{14}$ Os esforços do II PND visavam expandir a produção e as exportações de algumas indústrias de média intensidade tecnológica que foram seriamente prejudicadas pela crise da dívida e pela reforço dos setores econômicos americanos de baixa e média intensidade tecnológica em meados dos anos 1980 (Furtado, 1982, p. 36; Medeiros, 1998, p. 307).

${ }^{15}$ Para uma análise que também percebe que o subemprego nos países subdesenvolvidos assume uma dimensão substancialmente distinta daquilo que se apresenta nos países desenvolvidos, ver Hoffmann (1980, pp. 60-61).

${ }^{16}$ De acordo com Furtado (1982, pp. 36-38), a principal deficiência do II PND reside na incompatibilidade entre a participação da poupança interna nos recursos que financiaram a industrialização brasileira e os padrões de consumo que se pretendeu internalizar. O processo substitutivo, na medida em que internalizou setores de bens de consumo que iam para muito além da capacidade da renda média nacional, restringia o seu potencial de crescimento autônomo e de desenvolvimento, que ficou refém das oscilações do preço do dólar.
} 
ano de 1980, a participação das ocupações de baixa produtividade abrangia uma porção significativa da população ocupada, chegando a pouco menos de $30 \%$ do total, como exposto na subseção "Emprego, Subemprego e Desemprego (1980-2010)" deste artigo.

Como consequência da deterioração do parque industrial e das finanças do país, o que teria se iniciado de forma mais pronunciada nos anos 1980 e se prolongado nas décadas posteriores, foram exacerbados os mecanismos de crescimento das atividades de baixa produtividade. De um lado, a indústria urbana se enfraqueceu de forma profunda, sobretudo após o declínio da URSS, que acelerou a reorganização da produção em âmbito internacional. No Brasil, este processo se manifestou, sobretudo nos anos 1990, sob a forma de uma desindustrialização, que se caracterizou a) pela perda de elos da cadeia produtiva, principalmente nos setores intermediários e intensivos em tecnologia e capital; $b$ ) pela erosão dos centros internos de decisão, e $c$ ) pelo deslocamento do eixo dinâmico da economia para o exterior (Espósito, 2016, pp. 62-73). De outro lado, o agronegócio avançou rapidamente, retomando um espaço que perdera havia já várias décadas, selando o que (Coutinho, 1997) denominou de especialização regressiva.

Tal movimento revigorou o subemprego, que nas últimas décadas alcançou um nível muitas vezes mais elevado do que em meados do século passado. Ou seja, o desafio de civilizar o mercado de trabalho brasileiro tornou-se ainda maior, sendo três, basicamente, as suas razões econômicas: a) a situação crescentemente decadente da estrutura produtiva brasileira; $b$ ) o novo dimensionamento assumido pela dependência financeira, e $c$ ) o aumento do nível de trabalhadores sem ocupação ou ocupados em atividades de baixa produtividade. O desafio social que se impõe, portanto, à expansão da economia e às políticas de geração de renda e emprego são ainda maiores que no passado.

A deterioração das forças produtivas que se desenrola há mais de três decênios e que revitalizou as atividades primárias, como a mineração, a agricultura e a pecuária ${ }^{17}$ inviabiliza qualquer movimento mais consistente de melhora da estrutura ocupacional no Brasil. A perda de importância da indústria como geradora de postos de trabalho e a expansão da fronteira agrícola atuam conjuntamente para a deterioração da estrutura ocupacional e dos salários. O momento atual reafirma as atividades agrícolas e não-agrícolas como vasos comunicantes, embora o conjunto das migrações rural-urbanas seja muito menor que no passado. Mas aqui é preciso fazer uma ponderação importante. Em 2010, a população rural ultrapassava os 30000000 de pessoas, sendo que o subemprego rural era de aproximadamente 18000000 de pessoas. Esses números indicam que o campo brasileiro ainda se constitui como um importante reservatório de mão de obra para as atividades não-agrícolas, embora o seu fluxo migratório atual e o impacto socioeconômico não esteja mais tão concentrado nos grandes centros urbanos. Assim, os pequenos centros urbanos e as zonas rurais urbanizadas 18 são hoje mais afetados nas suas condições de vida e trabalho pela expansão da fronteira agrícola, o que continua a impactar negativa e indiretamente os grandes centros urbanos 19

Mas antes de avançarmos em nossa análise sobre o mercado de trabalho baseado no subemprego, é necessário apresentar os critérios que guiam a nossa metodologia bem como alguns contrapontos à dicotomização das ocupações entre emprego formal e informal.

\footnotetext{
${ }^{17}$ Para o fortalecimento de atividades empresariais na mineração e na agropecuária, ver Delgado (2012) e Oliveira (2007).

${ }^{18}$ Para uma qualificação do rural em suas várias dimensões, ver Carneiro (2018).

${ }^{19}$ Portugal Jr. (2012, caps. 8 e 9) estuda os impactos regionais da deterioração industrial e da migração rural.
} 


\section{Nota METODOLÓGICA}

A despeito das diferenças entre a metodologia tradicional -que analisa o mercado de trabalho com base nas categorias trabalho formal e informal-e a metodologia que utilizamos para mensurar o subemprego, existem algumas características comuns. Uma delas, em particular, nos interessa nesta breve exposição: ambas as pesquisas partem do princípio de que a heterogeneidade econômica e, pois, a heterogeneidade do mercado de trabalho pode ser percebida através da captação da produtividade do trabalho.

A construção da metodologia tradicional originou-se a partir de um documento publicado pela International Labour Office (1972). Neste trabalho, que analisava as causas e a dinâmica da heterogeneidade da economia queniana, procurou-se identificar as características principais das ocupações encontradas fora da moderna empresa capitalista, o que formaria aquilo que se denominou de setor informal e que depois seria disseminado em outros programas da Organização das Nações Unidas ${ }^{20}$ No âmbito da discussão latino-americana, o Programa Regional de Emprego para América Latina e Caribe cumpriu não só o papel de difundir o termo na região através de trabalhos como os de Tokman e Souza (1976) e Tokman (1978) como também avançou na formulação de um marco conceitual ${ }^{21}$ Nesse sentido, inseriu elementos que elevaram a sua precisão, sendo que um deles foi a identificação do setor informal com os estabelecimentos não-organizados, que eram destacados por Souza $(1980,1999)$ como estabelecimentos não tipicamente capitalista. Dentro de um espectro bastante heterogêneo, o setor informal compreendia desde as ocupações urbanas por conta própria que praticamente só contavam com o esforço físico do possuidor da força de trabalho até empresas com maior coeficiente técnico que perseguiam uma renda média que, mediante ajustes frequentes, remuneraria o capital e o trabalho. Em comum, esta gama variada de unidades produtivas que comporia o setor informal da economia teria como característica a incapacidade técnica ou tecnológica de reproduzir ampliadamente o seu capital e, pois, não seria apta a arcar com as despesas legais previstas em lei, o que contrastaria com o setor formal. Assim, essas novas resoluções eram captadas mediante a existência ou não de um contrato formal de trabalho, que se caracteriza pela exigência em se cumprir as leis trabalhistas. A inexistência deste tipo de contrato, para fins estatísticos, identifica as ocupações informais.

Todavia, é importante destacar ainda outras duas características que acompanham os trabalhos realizados no âmbito do Programa Regional de Emprego para América Latina e Caribe e que diferem consideravelmente da metodologia que defendemos neste trabalho. Uma delas é que essas pesquisas centravam fortemente suas atenções nas atividades não-agrícolas, o que, a despeito de algumas reformulações, gerou uma tradição que analisa as ocupações agrícolas apartadas das demais. ${ }^{22}$ Tal procedimento omite um elemento importante para a compreensão da totalidade econômica e, mais especificamente, da estrutura de ocupações. Perde-se de vista que a reprodução

\footnotetext{
${ }^{20}$ Segundo este documento, as características básicas das ocupações informais seriam $a$ ) facilidade de entrada, $b$ ) dependência de recursos locais-tradicionais, $c$ ) empreendimentos de propriedade familiar, $d$ ) operações de pequena escala, $e$ ) tecnologias adaptadas e intensivas em trabalho, $f$ ) capacidades laborais adquiridas fora do sistema educacional formal e g) identificação com os mercados competitivos e desregulados (International Labour Office , 1972, p. 6).

${ }^{21}$ Para uma revisão ampla do périplo percorrido pelo conceito de formalidade e informalidade, ver Cacciamali (2007), Mattos e Lima (2015) e Portugal Jr. (2012, cap. 4).

${ }^{22}$ Instituto Brasileiro de Geografia e Estatística [em diante IBGE] (1981) apresenta uma revisão ampla do debate dos anos 1970 sobre a marginalidade social, o subemprego, a formalidade, a não-formalidade e a informalidade do mercado de trabalho brasileiro. Aí revela-se que a discussão se pautava fundamentalmente na identificação e categorização das atividades urbanas, evidenciando uma negligência com relação às atividades rurais.
} 
das ocupações agrícolas e não-agrícolas de baixa produtividade ocorrem dentro daquele sistema de "vasos comunicantes" identificado por Prado Jr. (1987), que caracterizou a fundação da economia moderna no país e que permanece como elemento normal da organização econômica e social do país. Uma segunda característica destas pesquisas, de natureza estatístico-metodológica, residiria no critério usado para captar o objeto que se pretende apreender. Embora estes problemas sejam parte mesmo da natureza dos trabalhos estatísticos, que mais se aproximam do objeto do que o apreende em sua complexidade, o que problematizamos é a variável selecionada para perceber a heterogeneidade do mercado de trabalho. A posse da carteira de trabalho assinada não necessariamente corresponde a um trabalho de elevada produtividade ou que a unidade produtiva busque ou pratique a reprodução ampliada do capital, como é o caso dos trabalhadores e trabalhadoras domésticas que têm a carteira assinada. No sentido inverso, várias ocupações de elevada produtividade são realizadas à revelia da lei. Ambas estas situações, sobretudo a primeira, que representa um universo bastante significativo de toda a população ocupada, expressam um desvio do objetivo inicial da metodologia que não pode ser desconsiderado. Em suma, embora a metodologia tradicional perceba o total de ocupações protegidas pela legislação trabalhista, ela possui dificuldades flagrantes para capturar o perfil da estrutura ocupacional como uma expressão do estágio do (sub)desenvolvimento em que se encontra o país.

A metodologia elaborada por Octavio Rodríguez (1985) e apresentada minuciosamente por Portugal Jr. (1998, 2012), por sua vez, nos parece escapar dessas debilidades ${ }^{23}$ Em primeiro lugar, ela agrega em uma mesma dinâmica as atividades agrícolas e as atividades não-agrícolas. Mas não menos importante é a perspectiva de longo prazo desta metodologia, que se constitui em uma espécie de antídoto a hipóteses baseadas no curto prazo e que, por isso, reduz as possibilidades de se cair na tentação de exagerar avanços conjunturais que não encontram respaldo no movimento das estruturas econômicas. Partindo da concepção de que o subemprego em países periféricos é um fenômeno de longa duração, ou pelo menos de duração tão longa quanto a duração da articulação entre dependência externa e subdesenvolvimento, as análises baseadas nesta metodologia não poderiam se limitar a recortes temporais que expressam um período muito curto de tempo nem mesmo conjunturas específicas, ainda que porventura estas possam ter uma extensão temporal um pouco maior. Caso contrário, o exame do perfil e da evolução do subemprego como expressão do subdesenvolvimento ficaria prejudicado e se perderia, eventualmente, a sua principal característica, que é a percepção da sua permanência. Neste sentido, destacamos que esta metodologia tampouco se poderia valer de critérios estatísticos desafinados com a perspectiva de longo prazo, que obviamente difere do critério da carteira assinada, que por motivos conjunturais pode apresentar um crescimento mesmo em meio a processos de reversão da estrutura produtiva, como é o caso da conjuntura recente em que houve uma elevação da participação de ocupações formalizadas em meio a um contínuo processo de desindustrialização. Por isso, esta metodologia opta pela captação da produtividade do trabalho das atividades agrícolas e não-agrícolas através da

\footnotetext{
${ }^{23}$ Para maiores detalhes sobre a metodologia utilizada no trabalho seminal de Rodríguez (1985), ver Portugal Jr. (1998, 2012), que trabalhava na Fundação do Desenvolvimento Administrativo (Fundap) à época em que Rodríguez visitou a instituição, nos anos 1980, e, pois, teve participação na sua elaboração e conhece com intimidade a metodologia em questão. Aqui procuraremos apenas esclarecer os elementos metodológicos que se relacionam mais diretamente às preocupações deste capítulo.
} 
renda do trabalho: ${ }^{24}$ dado que a renda proporcionada pelo produto do trabalho em uma economia mercantil tende a expressar a dotação de capital da atividade em que o trabalho se encontra empenhado.

Todavia, definir a renda do trabalho como critério básico de análise é problemático, como enfatiza Hoffmann (1980, p. 62), pois a "igualdade entre o salário e a produtividade marginal” nem sempre se verifica em economias oligopolistas, como é o caso da economia brasileira. Para superar este impasse, Rodríguez (1985) e Portugal Jr. (1998, 2012) propuseram que se avaliasse a renda do empregador do estabelecimento como medida da produtividade da unidade produtividade, o que escapa do constrangimento óbvio de se confundir a produtividade do trabalho com a renda dos funcionários.

Além disso, é necessário definir um valor monetário que identifique uma linha limítrofe entre as atividades de baixa e de alta produtividade, o que não se mostra uma tarefa fácil, pois nem toda atividade estabelecida nos mercados de concorrência perfeita, digamos, rende remuneração tão baixa -ou seja, além da renda do trabalho, é necessário possuir outros instrumentos para captar ocupações que, pelas condições de trabalho comumente abaixo daquilo que socialmente se estabelece como digno, não classificam nem valorizam o possuidor da força de trabalho, o que caracterizaria também um subemprego, ainda que a renda auferida não seja das mais baixas, como seria o caso dos empregados e das empregadas domésticas. ${ }^{25}$ Esta medida se justifica pelo fato de que estas ocupações são resquícios de uma abolição da escravidão que esteve e que ainda está muito longe de esgotar todo o seu potencial construtivo (Fernandes 2008a; 2008b), o que evidencia a reprodução do subdesenvolvimento e o subemprego também desde um ponto de vista sociocultural.

Enfim, retomando mais de perto a discussão que identifica a renda do trabalho que distingue as atividades de alta e de baixa produtividade do trabalho, Portugal Jr. (1998, 2012) salienta que a renda em questão teria que ser aquela capaz de alterar significativamente as condições técnicas de produção - de outro modo, a renda escolhida deve expressar uma quantia monetária que seja destinada integralmente ao consumo. O próximo passo seria, então, o de inferir o valor monetário da renda do trabalho, o que se obteve através de testes de sensibilidade realizados com cortes de um e dois salários mínimos (Portugal Jr., 2012, p. 411). Dentro destes parâmetros, a renda de dois salários mínimos foi identificada como o valor que se encaixava melhor ao critério selecionado, o que significa que as rendas superiores a este valor se mostravam factíveis com a possibilidade de se elevar a densidade de capital de um trabalhador autônomo ou de uma unidade produtiva de pequeno porte. Ao mesmo tempo, buscou-se a identificação de um valor monetário que não se

\footnotetext{
${ }^{24}$ Esta discussão é de natureza diferente, portanto, daquela que critica a percepção da pobreza e da desigualdade social unicamente a partir da renda do trabalho, como se verifica em Dedecca (2012).

${ }^{25}$ Esta observação metodológica procura avançar sobre os limites das metodologias que restringem a percepção do subemprego apenas à produtividade baseada na renda do trabalho, do que escaparia a diversidade de uma economia extremamente heterogênea como a brasileira, como é salientado em IBGE (1981, pp. 26-27). Além disso, é importante salientar que a metodologia desenvolvida por Rodríguez e Portugal Jr. tem o mérito de captar formas de ocupação que não classificam nem valorizam o portador da força de trabalho, ainda que os autores não se coloquem a questão nestes termos.
} 
deteriorasse no longo prazo ${ }^{26}$ o que somente ocorreria no caso de uma elevação real considerável tanto do nível médio dos salários como também do nível do salário mínimo em um espaço temporal bastante dilatado -neste sentido, entendemos não haver razões para reconsiderar a renda de dois salários mínimos como critério básico da pesquisa, pois a elevação do salário mínimo real nos últimos anos não apenas ocorreu dentro de um período relativamente curto (2005-2015), e que parece ter os seus dias contados após a promulgação da emenda constitucional 95, como tampouco alcançou valores mais consideráveis. 27

Outro aspecto da pesquisa que é necessário elucidar corresponde às posições que os trabalhadores classificados como subempregados e empregados ocupam na estrutura de ocupações -afinal, nem todos aqueles identificados como empregados trabalham para alguém. Alguns destes trabalhadores são autônomos ou empregadores-empresários. E aqui cabe uma ressalva importante: como é impossível verificar a renda auferida pelas empresas, a renda mensal média que se utiliza para captar a produtividade do trabalho dessas unidades produtivas é a renda do empregador, que não só expressa com maior acuidade a produtividade dos meios de produção que se disponibiliza à força de trabalho ocupada como também representa uma aproximação mais fiel da renda que pode ser empenhada na ampliação do capital. Assim, a categoria empregados abrangeria os empregadores que recebem uma remuneração mensal média acima de dois salários mínimos, os funcionários destes empregadores e os ocupados por conta própria que auferem uma remuneração média maior que dois salários mínimos por mês. De forma análoga, os subempregados seriam representados pelos empregadores que recebem até dois salários mínimos, pelos trabalhadores ocupados nestas unidades, pelos trabalhadores autônomos que recebem até dois salários mínimos e, por definição, pelos ocupados não remunerados e pelos empregados domésticos 28

Assim, se considerarmos que o objetivo de examinar a dinâmica e a estrutura do mercado de trabalho é evidenciar o estágio do desenvolvimento, esse procedimento impede que incorramos em equívocos como seria o de superestimar o emprego, tal como o entendemos, na estrutura ocupacional. Através destes expedientes procurou-se reduzir a deformação desta metodologia, sobretudo porque uma das ocupações de maior peso isolado na população ocupada é justamente a de serviços domésticos. Embora a garantia legal de direitos trabalhistas seja importante, é necessário pontuar que a formalização de uma dada atividade de baixa produtividade, e que mesmo assim costuma incorrer em uma série de abusos por parte do empregador, a mesma não corresponde à eliminação de sua reprodução.

\footnotetext{
${ }^{26}$ Ainda que trate de outros propósitos, Medeiros (2015, p. 73) nos auxilia a confirmar a validade do critério utilizado na pesquisa na medida em que infere que mesmo no período 2008-2009 os dados da Pesquisa de Orçamentos Familiares indicaram que o perfil do consumo muda consideravelmente quando se passa da faixa de renda de dois salários mínimos para as demais, quando se tornariam mais frequentes a posse de bens como o computador, eletrodomésticos e, sobretudo, o automóvel.

${ }^{27} \mathrm{O}$ salário mínimo ainda se encontra em patamar bastante reduzido, insuficiente sequer para atender de forma satisfatória as necessidades básicas do trabalhador brasileiro. E aqui lembramos que o valor do salário mínimo calculado pelo Departamento Intersindical de Estatística e Estudos Socioeconômicos (2016), baseado nos preceitos da Constituição de 1988, que atesta que o salário mínimo deveria ser "capaz de atender às necessidades vitais básicas (do trabalhador) e às de sua família com moradia, alimentação, educação, saúde, lazer, vestuário, higiene, transporte e previdência social” (p. 10), é aproximadamente quatro vezes superior ao do salário mínimo nominal.

${ }^{28}$ É importante que o leitor compreenda que, neste caso específico em que identificamos as posições ocupacionais que compõem os termos subempregados, não nos passou despercebido que nem todos os trabalhadores identificados como subempregados trabalham para alguém. Alguns deles são autônomos ou mesmo empregadores, como salientado acima. Todavia, o que importa aqui é criar uma nomenclatura sintética.
} 
Embora a metodologia que apresentamos também possua limitações, o que é da natureza mesmo de um trabalho estatístico, como já afirmamos, entendemos que ela percebe algumas das principais características socioeconômicas do subdesenvolvimento latino-americano, que não pode ser resumida à dinâmica urbano-industrial. Ela tampouco negligencia aspectos de nossa herança colonial que nos parecem fundametais para a composição da estrutura ocupacional e, consequentemente, para o perfil da demanda, que seria precisamente um dos aspectos mais importantes para a formação do anel de feed-back tal como apontado por Furtado (1972). Pelo contrário, a metodologia desenvolvida por Octavio Rodríguez e José Geraldo Portugal Jr. incorpora à análise da dinâmica industrial a segregação social decorrente do passado escravista e a expulsão de trabalhadores agrícolas como alguns dos fundamentos da dinâmica econômica e do mercado de trabalho brasileiro. Por isso, na medida em que ela entende este movimento como parte intrínseca de uma economia extremamente heterogênea que ainda é dependente das finanças e da tecnologia originadas nos países centrais e hegemônicos, os resultados obtidos são válidos como reflexo desta realidade concreta. Diante do tamanho da população rural, imersa em relações sociais que também são o resultado de séculos de escravidão, e do crescente papel que cumpre a agricultura de exportação na dinâmica econômica do país, seria um erro desprezar essa realidade como um fator de pressão sobre o perfil das estruturas de ocupações e de remuneração.

\section{EMPREGO, SUBEMPREGO E DESEMPREGO (1980-2010)}

Realizado o percurso metodológico, acreditamos já termos apresentado elementos suficientes para permitir uma compreensão mais precisa da análise do mercado de trabalho baseada na categoria de subemprego desenvolvida por Rodríguez (1985) e Portugal Jr. (2012). Agora nos cumpre incorporar os números que dão base ao exame estrutural da dimensão socioeconômica da economia brasileira.

Há uma inflexão evidente na economia brasileira a partir dos anos oitenta. A partir da Crise da Dívida, as condições mais gerais da economia brasileira se deterioraram, revertendo um fluxo que se iniciara nos anos 1930. Esse movimento nos leva a crer que um olhar um pouco mais detido sobre os anos 1980 nos parece fundamental para se compreender a nova orientação dada à economia brasileira, que a partir daquele momento ingressou em uma trajetória de declínio estrutural acentuado. Mais detidamente no que se refere à estrutura ocupacional, observa-se um crescimento abrupto dos subempregados. O nível de ocupados em atividades de baixa produtividade do trabalho passou de 12100 000, em 1980, para 26400 000, em 1991 (ver tabela 1).

A pressão externa que pairava sobre a economia brasileira para se obter divisas abalou de duas formas a geração de postos de trabalho no país. De um lado, a expansão da produção agrícola de grande escala e altamente mecanizada passou a reproduzir em escala ampliada o subemprego rural, identificado com as unidades de subsistência. Entre 1980 e 1991, houve um acréscimo de pouco mais de 2000000 de subempregados rurais, o que não necessariamente quer dizer que as precárias condições de vida e trabalho no Brasil rural tenham gerado "apenas" 2000000 de ocupações de baixa produtividade. Uma parcela não desprezível de trabalhadores rurais migrou para atividades não-agrícolas, estivessem estas localizadas em centros urbanos ou em zonas rurais que 


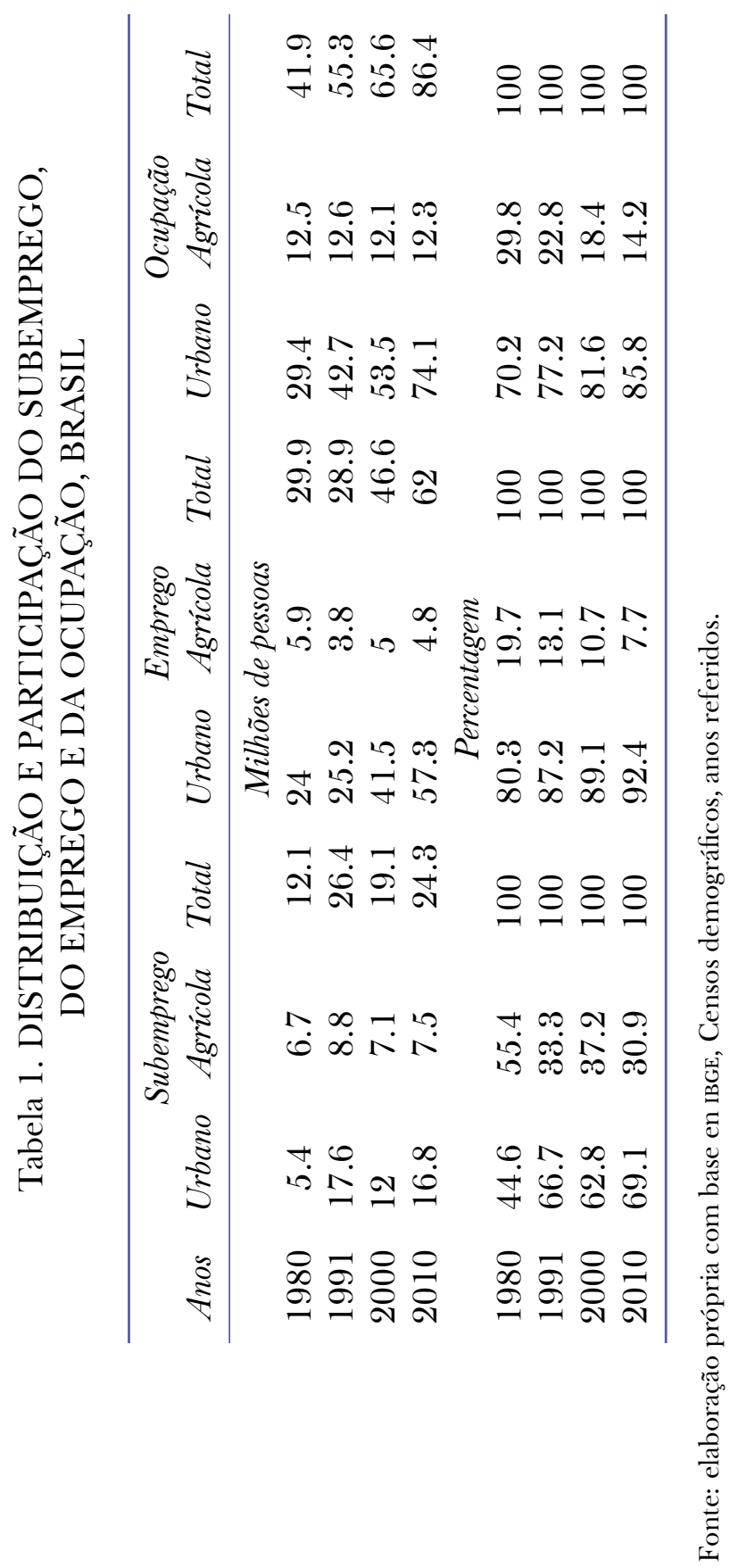


passaram por um processo de urbanização. ${ }^{29}$ Com poucas perspectivas de serem absorvidos pelo agronegócio e impulsionados pela miséria que avançava no campo, muitos migraram, sobretudo, aos centros urbanos, onde tende a ser maior a demanda de trabalho. Todavia, há que se ponderar que as condições nos centros urbanos do país não eram promissoras, o que nos leva à segunda ordem de problemas que modificaram a estrutura ocupacional do país. Em um momento de modificação profunda na divisão internacional do trabalho, os setores industriais que tinham alguma vazão para os mercados externos tanto perderam competitividade internaciona 30 quanto passaram a sofrer maior concorrência da indústria americana na segunda metade da década de 1980 31 o que exigiu uma queda nos custos variáveis sem que a quantidade produzida fosse gravemente afetada. Ou seja, o ajuste competitivo local das filiais das empresas transnacionais redundou em demissões e no aumento da taxa de exploração sobre o trabalhador que manteve o seu emprego. Como resultado, muitos foram obrigados a encontrar uma estratégia de sobrevivência fora das fábricas e dos estabelecimentos que prestavam serviços às mesmas. Apesar de um acréscimo de 1200000 de empregos em atividades não-agrícolas na década de 1980, o crescimento das atividades de baixa produtividade nos centros urbanos foi muito superior, passando de 5400000 para 17600 000. Assim, a população rural que fugia da deterioração das condições de vida e trabalho no campo, e que se somava à população pobre que já residia nas cidades, foi engolida por uma crise de grandes proporções.

Mas a expansão contínua do latifúndio agromercantil se estendeu para além dos anos 1980, concorrendo fortemente para tornar a oferta de trabalho agrícola ainda mais excedente nas décadas posteriores. A quantidade de empregos agrícolas verificada em 1980 não foi retomada nem mesmo em 2010, quando a produção e a produtividade das lavouras para exportação eram já muito maiores que no início do período analisado (ver tabela 1). Os processos de desindustrialização e de especialização regressiva, que progrediram nos anos 1990 e 2000, atestam que a Crise da Dívida foi apenas uma das primeiras expressões de um movimento muito mais profundo que vem alterando o perfil da estrutura das ocupações rurais. Entre 1980 e 2010, por exemplo, a participação do subemprego agrícola passou de 52.8 para 61\% ${ }^{32}$ Segundo Delgado (2012, p. 116), o aumento da produção e da exportação das principais cadeias agroindustriais ${ }^{33}$ baseadas sobretudo na exploração de recursos naturais, não propaga o progresso técnico que abre fronteiras à acumulação de capital, não abre novos mercados interindustriais nem leva ao aumento da demanda por

${ }^{29}$ As proporções relativamente baixas da população rural (15\%) da população brasileira, geralmente são utilizadas como argumento básico para desqualificar a questão agrária como determinante das atuais condições de trabalho e remuneração no Brasil. Todavia, essas análises subestimam não apenas as fragilidade das estruturas econômicas do país como também subestimam que estes 15\% representam 30000000 de pessoas, das quais aproximadamente 18300 000 viviam da subsistência.

${ }^{30}$ Segundo Suzigan (1992), a incorporação da eletroeletrônica nos processos produtivos localizados no Estados Unidos, Europa Ocidental e no bloco asiático liderado pelo Japão, tornou a indústria instalada no Brasil crescentemente obsoleta.

${ }^{31}$ Para o avanço dos setores produtivos de baixa e média intensidade de tecnologia e capital no Estados Unidos, o que abrangeu tanto setores industriais quanto setores agrícolas, ver Medeiros (1998, p. 307).

${ }^{32}$ Para uma análise crítica da reforma agrária no Brasil entre 1964 e a primeira década do século xxi, ver Oliveira (2007, pp. 120-173).

${ }^{33}$ Castilho (2012) apresenta informações importantes sobre o financiamento de grandes empresários do agronegócio a parlamentares eleitos nas esferas municipal, estadual e federal. 
Tabela 2. VARIAÇÕES ANUAIS DO SUBEMPREGO, DO EMPREGO E DA OGUPAÇÃO, PERGENTAGEM, BRASIL

\begin{tabular}{|c|c|c|c|c|c|c|c|c|c|}
\hline \multirow[b]{2}{*}{ Anos } & \multicolumn{3}{|c|}{ Subemprego } & \multicolumn{3}{|c|}{ Emprego } & \multicolumn{3}{|c|}{ Ocupação } \\
\hline & Urbano & Agrícola & Total & Urbano & Agrícola & Total & Urbano & Agrícola & Total \\
\hline $1991-1980$ & 224.9 & 32 & 118.4 & 4.99 & -36 . & -3.2 & 45.4 & 0. & 31.8 \\
\hline $2000-19$ & 121.7 & 6.3 & 58 & 73.1 & -14 & 55.9 & 82.1 & -3.4 & 56.5 \\
\hline 2000-1991 & -31.8 & -19.5 & -27.7 & 65 & 34.2 & 61 & 25.2 & -3.5 & 18.7 \\
\hline $2010-2000$ & 40.4 & 5.7 & 27.5 & 37.9 & -5.3 & 33.2 & 38.5 & 1.1 & 31.6 \\
\hline 2010-1 & -4.2 & -14.9 & -7.8 & 127.5 & 27.1 & & & -2.4 & 56.2 \\
\hline $2010-1980$ & 211.2 & 12.3 & 101.4 & 138.8 & -18.9 & 107.7 & 152.1 & -2.3 & 105.9 \\
\hline
\end{tabular}

Fonte: elaboração própria com base en IBGE, Censos demográficos, anos referidos.

bens finais. Segundo este autor, nem mesmo um crescimento da agroindústria na casa dos $10 \%$ ao ano entre 2000 e 2005 conseguiu oferecer garantias ao aumento da ocupação, dos salários e da massa de salários.

Mas a quantificação da população trabalhadora apta e disposta a ocupar um posto de trabalho em atividades agrícolas depende ainda de um outro componente que é de difícil captação. Em 2010, embora nossa pesquisa indique que os trabalhadores ocupados em atividades rurais de baixa produtividade tenham passado a 7500 000, o que significa um decréscimo de 1300000 com relação a 1991, acreditamos que este seja um número subestimado quando se trata de analisar a população disponível para participar dessas atividades. Parte da população urbana, que muitas vezes é de origem rural e ainda mantém vínculos com o trabalho do campo, busca ocupações irregulares nas atividades agrícolas e não-agrícolas ao sabor da ocasião, compondo com a população trabalhadora já ocupada em atividades agrícolas uma superpopulação latente de grandes dimensões ${ }^{34}$ Devido às dificuldades de se encontrar um emprego não-agrícola, para muitos a solução acaba sendo migrar constantemente entre o subemprego rural e o subemprego urbano, sendo que desde os anos 1980 as cidades de pequeno e médio porte passaram a receber um fluxo muito maior de migrantes do que nas décadas anteriores ${ }^{35}$ A grande diferença é que a atual estrutura industrial brasileira não possui mais uma grande capacidade de absorção da mão de obra nem a mesma interlocução com os serviços urbanos de alta produtividade que havia em meados do século xx -e aqui nota-se uma dimensão notável da estrutura ocupacional que emergiu nos anos 1980: o crescimento do subemprego urbano. Embora as atividades não-agrícolas de alta produtividade tenham percebido um acréscimo considerável no período, é preocupante a constatação de que a participação do subemprego urbano cresceu ainda mais, para o que os serviços de baixa produtividade contribuíram significativamente.

\footnotetext{
${ }^{34}$ Para Marx (2013), na medida em que a produção capitalista se apodera da agricultura, irremediavelmente irá surgir uma população sem possibilidades de encontrar outra ocupação agrícola e que, por isso, se encontrará "em vias de se transferir para o proletariado urbano ou manufatureiro, e à espreita de circunstâncias favoráveis a essa metamorfose" (p. 717), configurando-se como uma superpopulação latente, "sempre com um pé no lodaçal do pauperismo." (p. 718).

${ }^{35}$ Para uma análise dos movimentos regionais do mercado de trabalho nas décadas de 1980, 1990 e 2000 , ver Portugal Jr. (2012, itens 8.5-8.6 e 9.5-9.6).
} 
Em 2010, eram 16800000 os trabalhadores ocupados em atividades urbanas de baixa produtividade, o que totalizou $69.2 \%$ de todo o subemprego no país. ${ }^{36}$ Isso significa, de um lado, que o subemprego urbano se consolidou como a principal alternativa à inexistência de ocupações de elevada produtividade em quantidade suficiente à absorção de toda a oferta de trabalho -o que,de certo modo, acompanhou a transformação demográfica do país, que passou a contar com uma maioria urbana apenas no decorrer da década de 1960. De outro, observa-se que o nível de subempregados resiste em regressar a níveis inferiores àqueles encontrados em 1980. As taxas de crescimento do emprego e do subemprego da tabela ?? atestam que a abertura de postos de trabalho de alta produtividade é insuficiente para atender o crescimento da oferta de trabalho.

Ao longo do período analisado, a economia deu sinais claros de que não possuía meios para dar continuidade ao desenvolvimento das forças produtivas tal como ocorrera entre 1930 e 1980. Nesse sentido, observamos que, entre 1980 e 2010, o crescimento do subemprego urbano, de $211.2 \%$, foi superior ao crescimento do emprego das atividades não-agrícolas, de $138.8 \%$. De modo análogo, a evolução das ocupações rurais também indica um acirramento das contradições entre capital e trabalho no mesmo período. Enquanto o emprego apresentou queda de $18.9 \%$, o subemprego apresentou uma variação positiva de $12.3 \%$ ao longo destes 30 anos.

Sem condições de acompanhar o ritmo da demanda de trabalho, o lento e vacilante crescimento econômico proporcionou não apenas este contínuo acréscimo de subemprego como também permitiu um aumento da taxa de desemprego, cuja dinâmica não deve ser compreendida de modo isolado. Há uma complementaridade entre o subemprego e o desemprego, visto que ambas estas variáveis refletem a insuficiência da estrutura produtiva em absorver a força de trabalho disponível. Se, de um lado, refugiar-se em uma atividade de baixa produtividade representou uma estratégia de sobrevivência bastante procurada nos anos 1980, o aumento do desemprego nos anos 1990 refletiu o esgotamento do subemprego como alternativa (ver gráfico 1).

Após a reversão do ciclo expansivo que se seguiu à irrupção da Crise da Dívida, o subemprego disparou, alcançando a impressionante marca de $47.7 \%$ da população ocupada, em 1991, o que representou um acréscimo de quase 19 pontos percentuais com relação a 1980. No mesmo período, o desemprego cresceu com menor intensidade, passando de dois para 5.4\%. Foi apenas na década seguinte, quando o processo de liberalização da economia acelerou, que o desemprego assumiu grandes proporções, chegando a $15.3 \%$ da população economicamente ativa (PEA), o que revelaria a crescente dificuldade em se fazer do subempregado uma estratégia de sobrevivência diante de um PIB tão baixo e oscilante. Mas a queda na participação de subempregados entre 1991 e 2000 não parece estar ligada apenas ao esgotamento do subemprego como estratégia de sobrevivência -afinal, a queda no subemprego é mais que proporcional ao aumento do desemprego. Durante a década de 1990, parte importante da PEA foi absorvido em atividades de produtividade mais elevada, o que deve ser visto com ressalvas. A maioria das ocupações criadas neste período

\footnotetext{
${ }^{36}$ Parece-nos plausível afirmar que a maior parte da massa de subempregados urbanos alternaria simplesmente de um subemprego não-agrícola para outro de mesmo tipo. De tal modo, esta população poderia ser identificada à superpopulação estagnada, tal como apresentou Marx (2013). Para este autor, esta fração da classe trabalhadora formaria "uma parte do exército ativo de trabalhadores, mas com ocupação totalmente irregular. Desse modo, ela proporcionaria ao capital um depósito inesgotável de força de trabalho disponível. Sua condição de vida cai abaixo do nível médio normal da classe trabalhadora, e é precisamente isso que a torna uma base ampla para certos ramos de exploração do capital" (p. 718). Para uma análise marxista que identifica a população estagnada ao emprego informal, ver Nakatani e Sabadini (2002). Hoffmann (1980, p. 60) também apresenta análise semelhante.
} 


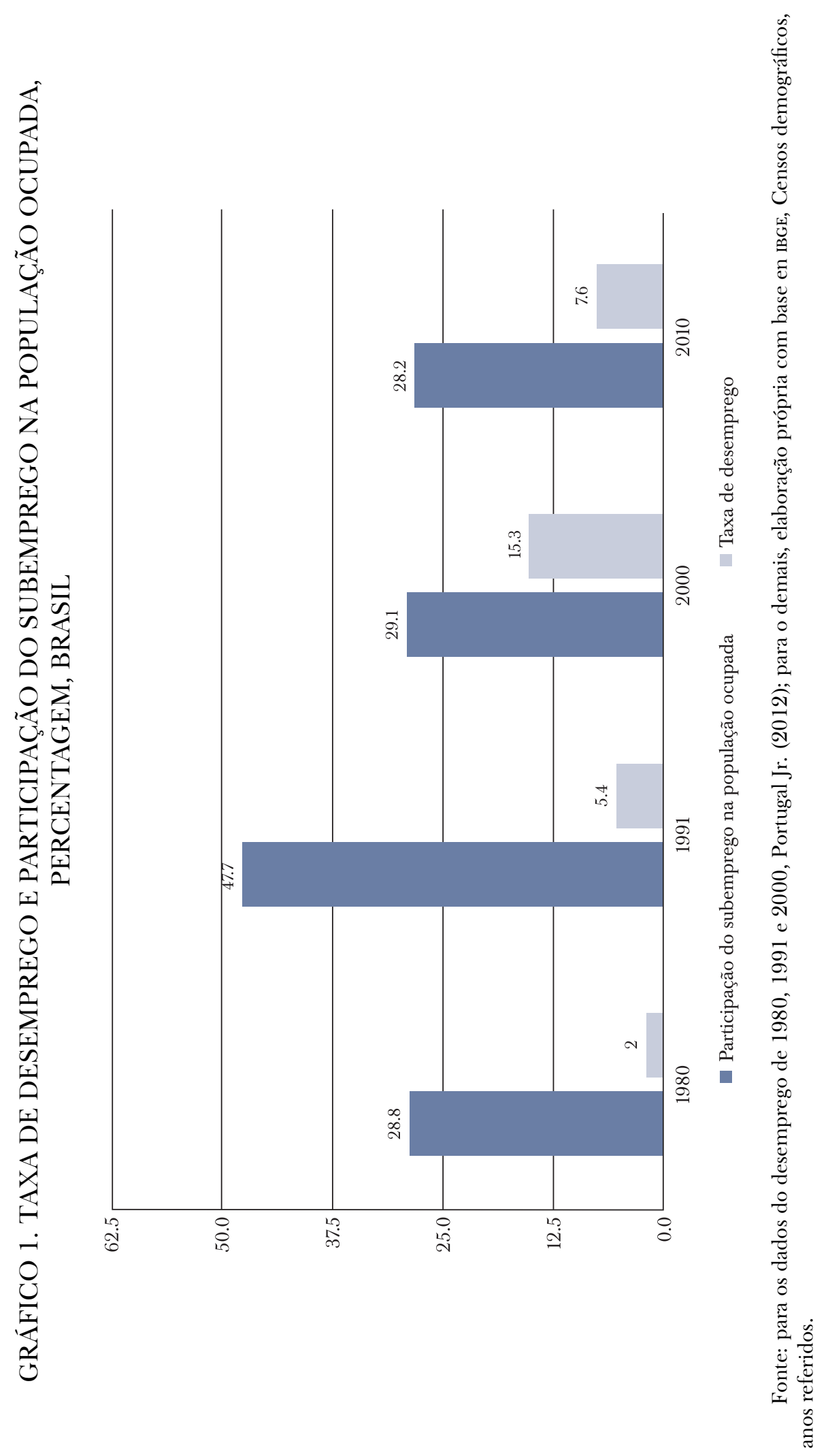


são ocupações terciárias, que tradicionalmente oferecem salários mais baixos e proteção sindical menor que os trabalhos na indústria de transformação, que apresentou queda na participação da estrutura ocupacional.

Nos anos 2000, quando o crescimento médio do produto foi alto em comparação com a década anterior, o desemprego apresentou uma queda considerável, baixando cerca de oito pontos percentuais, chegando a 7.6\% da PEA. Todavia, a expansão econômica não foi suficientemente elevada para que a taxa de desemprego se aproximasse do patamar verificado em 1980. Paralelamente, observamos que, devido à deterioração da estrutura econômica, que não conseguiu estabelecer uma dinâmica mercantil mais forte, o crescimento econômico não foi suficiente para reduzir substancialmente a taxa de subemprego, que no ano de 2010 chegou a $28.2 \%$, índice bastante próximo ao que se verificou em 2000. Isso significa que desde, uma perspectiva mais geral, a criação de empregos e subempregos do período se deu em um ritmo muito semelhante (ver tabela 2).

Embora na última década o desemprego tenha sofrido uma retração importante e o subemprego retornado a taxas semelhantes às da década de 1980, o perfil da atual estrutura ocupacional é muito mais frágil. A desestruturação que atravessa a economia, aliada ao crescimento do desemprego estrutural próprio da modernização dos meios de produção, levou a uma queda no número de empregos nos ramos mais intensivos em capital e tecnologia da indústria de transformação, que passou de $2500000 \mathrm{em} 1980$ para $1300000 \mathrm{em} 2010$ (ver tabela 3). Esta queda do número absoluto de empregados das indústrias dinâmicas representou uma diminuição ainda maior na participação destes empregados na população ocupada nas indústrias manufatureiras, que passou de $36.1 \%$ em 1980 para $12.5 \%$ em 2010.

A queda do emprego nos setores industriais mais dinâmicos aponta para uma perda de representatividade muito grande também quando analisada junto à população ocupada (ver tabela 4 ). Nessa relação, a sua participação passou de 6\%, em 1980, para 1.5\%, em 2010. De modo análogo, houve um decréscimo na participação do emprego na indústria tradicional, ainda que em ritmo um pouco mais lento. Apesar do emprego ter quase que dobrado, indo de 4100000 a 7600000 , sua participação no total de ocupados também declinou, passando de 9.8 a $8.8 \%$, o que evidencia que o setor manufatureiro como um todo perdeu espaço na geração de postos de trabalho na economia brasileira.

A partir da obsoletização do parque industrial brasileiro, nos anos 1980, e da perda de elos da cadeia produtiva, que avança decididamente a partir da década de 1990, não houve apenas uma retomada de formas de ocupação que se caracterizam pela baixa produtividade e pela baixa remuneração do trabalho. Muitos dos que perderam seus empregos no setor secundário e no setor primário, além de muitos que ingressaram à PEA, encontraram uma ocupação no setor terciário, que já em 1991 era o setor mais representativo da estrutura ocupacional, perfazendo mais da metade da população ocupada (ver tabela 5). Neste ano, o nível de ocupação no setor terciário era de $54.8 \%$, o que representou um acréscimo de 9.3 pontos percentuais com relação a 1980.

Na década de 1980, a grande maioria destas pessoas se refugiou nas atividades terciárias de baixa produtividade do trabalho, que passou a abrigar 13900 000, o que representou um acréscimo de 9400000 de subempregados em pouco mais de dez anos. Em termos relativos, este aumento representou um salto igualmente expressivo na participação das atividades terciárias no subemprego, passando de 37.6 para $52.8 \%$ do total dos ocupados em atividades de baixa produtividade. Nas duas décadas posteriores, marcadas pela liberalização aberta da economia, o seu patamar foi elevado, chegando a $55.8 \%$ em 2010, o que evidencia que a transformação do setor 


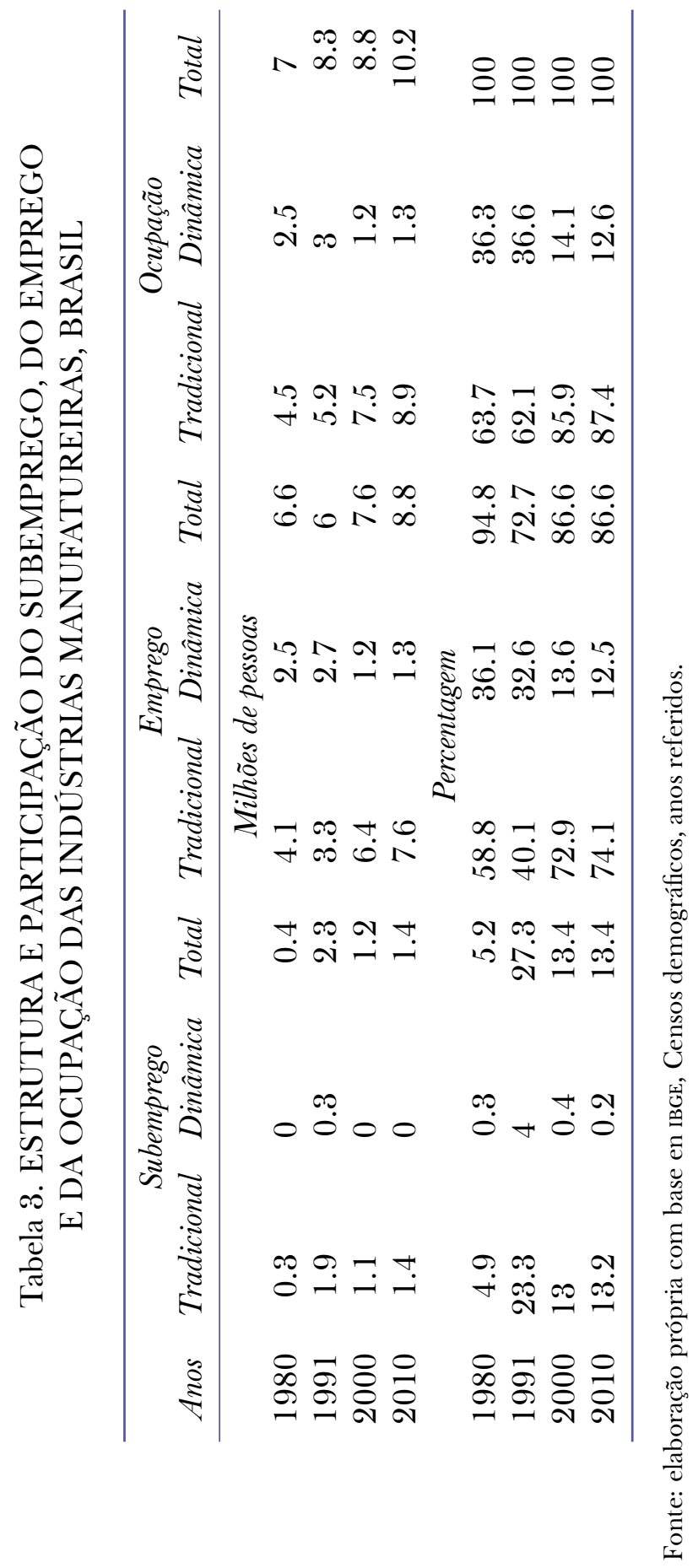




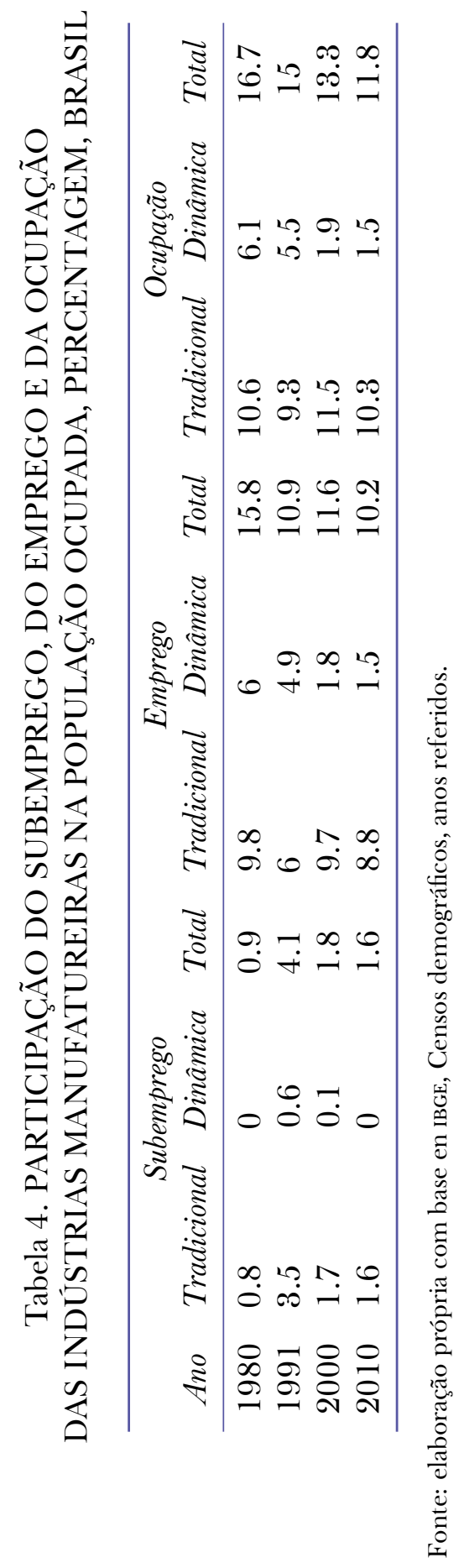




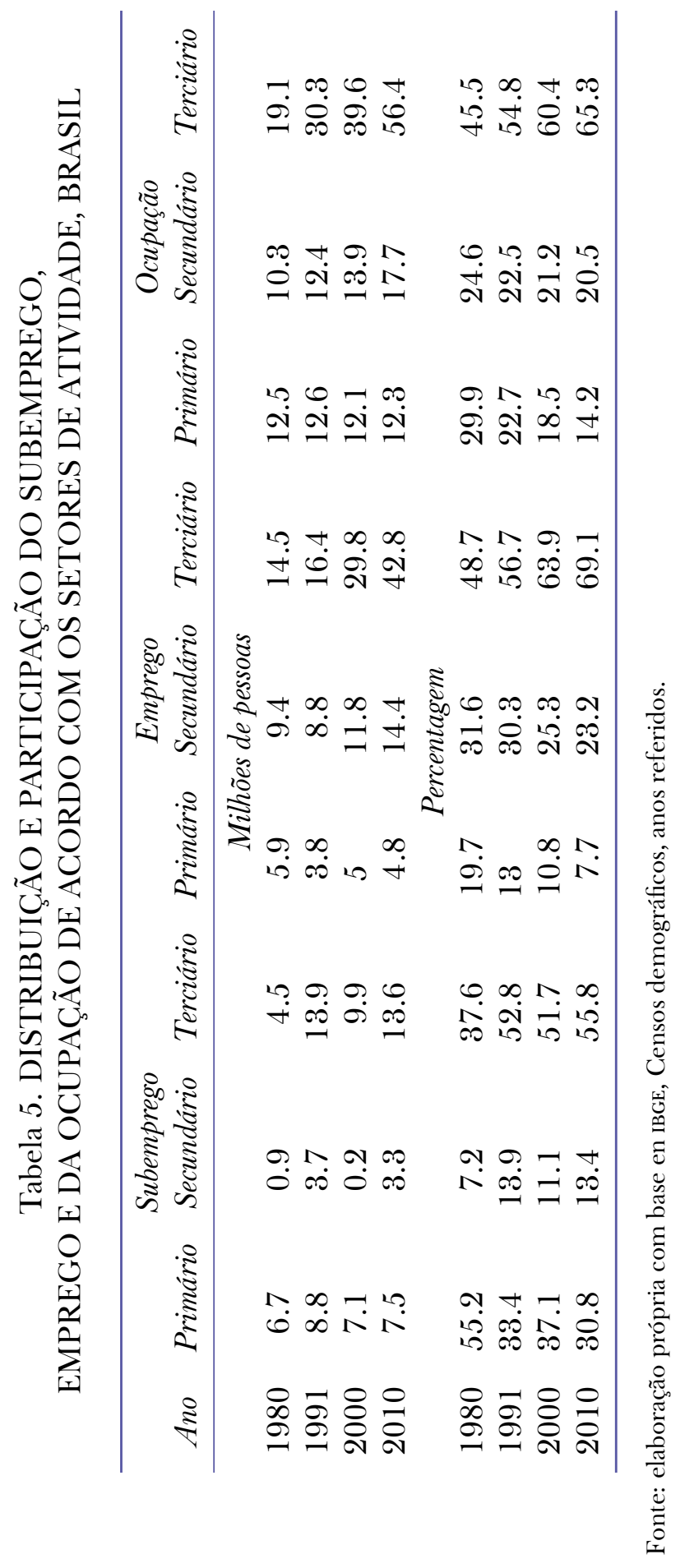


terciário no setor com maior participação na população ocupada e com maior participação no total de subempregados não foi uma mudança conjuntural trazida pela Crise da Dívida. O setor terciário da economia brasileira continuou a se destacar pelos serviços pessoais e outras formas de ocupação de baixa produtividade, o que nos permite identificá-lo como o maior depositário de mão de obra ocupada em atividades de baixa produtividade, substituindo um posto que anteriormente era ocupado pelo setor primário (ver gráfico 2). De outro modo, o que se nota é uma reconfiguração da heterogeneidade estrutural no país.

A despeito do subemprego no setor primário ter preservado, em 1991, a mesma participação apresentada em 1980 -15.9\%-, o subemprego no terciário cresceu quase quinze pontos percentuais, passando a $25.2 \%$. Nos anos seguintes, quando a participação do subemprego caiu e o setor terciário se consolidou como o principal absorsor de atividades de baixa produtividade, os serviços pessoais, similares e outros alcançaram $10.6 \%$ da população ocupada em 2010 , superando de forma isolada a participação das ocupações primárias de baixa produtividade.

Em suma, o quadro que montamos procurou evidenciar, acima de tudo, que as articulações entre as atividades agrícolas e não-agrícolas, embora tenham perdido a evidência que já possuíra, continuam a jogar papel relevante na determinação do perfil das ocupações urbanas. Tentamos apresentar evidências de que a constante expulsão de mão de obra agrícola ainda é um componente significativo na alimentação das ocupações não-agrícolas de baixa produtividade, sobretudo terciárias, que hoje se encontram também disseminadas entre os centros urbanos de menor densidade populacional e industrial -e este nos parece um ponto fundamental. Embora o êxodo rural provocado pela contínua expansão da fronteira do agronegócio não seja mais tão grande como foi em meados do século xx, a atual dinâmica da indústria urbana nacional não favorece a criação de empregos não-agrícolas.

De um lado, a divisão internacional do trabalho que emerge na década de 1980 impôs uma regressão à indústria urbana exatamente em um momento em que a população já era majoritariamente urbana. Ou seja, a degradação da indústria de transformação iniciada ainda nos anos 1980 levou a um aumento do desemprego e do subemprego, sobretudo do subemprego urbano. De outro lado, a expansão das atividades agrícolas não levou a um aumento da demanda por trabalho agrícola, o que significa que o subemprego rural não apenas continuou a ser reproduzido como também continuou a produzir uma grande quantidade de trabalhadores rurais dispostos a se deslocar para atividades não-agrícolas. Assim, a heterogeneidade estrutural que singulariza a sociedade brasileira assumiu uma nova composição que apresenta duas características básicas. Primeiramente, ocupações de elevada produtividade do setor secundário foram, em boa medida, substituídas pelo desemprego, por empregos de menor qualidade e por subempregos, havendo em ambos os casos um predomínio de ocupações terciárias. Em segundo lugar, o desemprego aberto em larga escala se consolidou. Todavia, sua manifestação não possui sempre a mesma intensidade. Nos anos 1980 e no começo em 2010, por exemplo, ele se manifesta de modo sorrateiro, pois, a despeito da taxa de desemprego ter apresentado patamares relativamente baixos, a estrutura econômica nacional se deteriorou em ambos os momentos. Em outros momento, como a década de 1990, quando a população trabalhadora não conseguia sequer uma ocupação de baixa produtividade, o desemprego emerge com mais intensidade e escancara a fragilidade de nossa economia. Se nas conjunturas internacionais favoráveis ao crescimento periférico o desemprego foi mitigado mesmo na ausência de um processo de revitalização da estrutura produtiva, é nas conjunturas internacionais desfavoráveis que o desemprego aberto emerge de forma abrupta e evidencia a possibilidade de reversão à qual fazemos advertência desde 2014 (Zullo, 2014). 


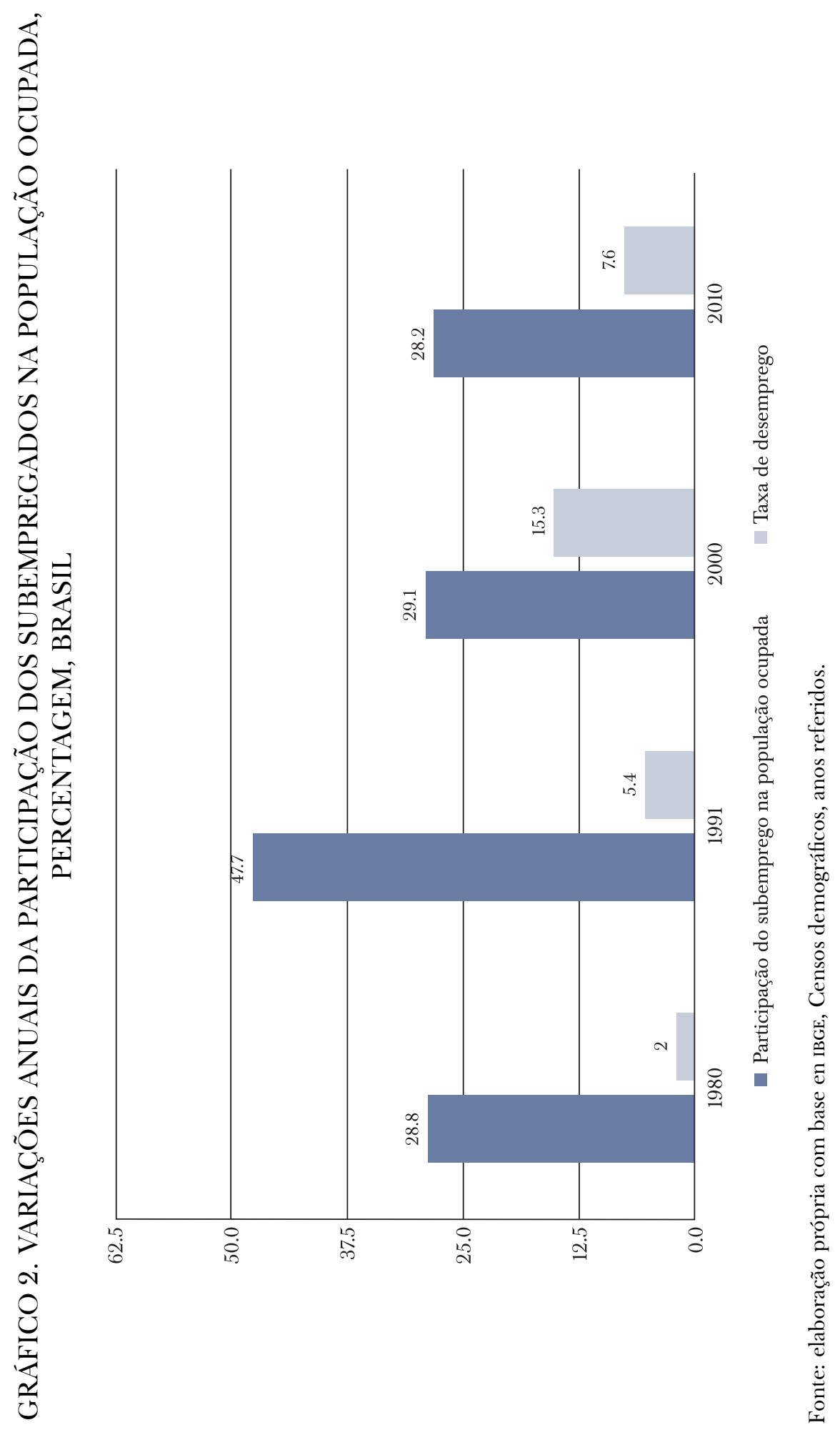




\section{ConsideraÇÕES FINAIS}

Combalida, a economia brasileira impõe dificuldades ao enfrentamento do processo de regressão das forças produtivas, que, estendida para a totalidade da realidade concreta, assume a forma de uma reversão neocolonial. ${ }^{37}$ Como consequência, a classe trabalhadora está exposta a uma situação extremamente precária, revelando os limites de um país que não transformou as suas estruturas econômica, sociocultural e política. Embora a participação das ocupações de baixa produtividade seja muito semelhante nos anos de 1980 e de 2010, o nível de subempregos e de desempregados praticamente dobrou neste mesmo período. Mesmo na última década, comumente celebrada como um período de grande progresso econômico e de organização do mercado de trabalho, nossa análise não revelou indícios significativos de que o processo regressivo, que há décadas atravessa as estruturas e a dinâmica do país, tenha sido obstado. Pelo contrário, a economia continua carente do anel de feed-back salientado por Furtado (1972). Mas não apenas isso: as condições de trabalho e remuneração das atividades agrícolas e não-agrícolas continuam a operar como vasos comunicantes, deteriorando-se mutuamente - a redução do grau e da intensidade com que este processo se desenrola hoje em dia não justifica a desvinculação dos setores agrícola e não-agrícola, que devem ser estudados em sua totalidade e dentro de horizontes temporais mais longos, e não de modo fracionado e conjuntural.

O desafio que hoje se coloca à superação do subdesenvolvimento e da heterogeneidade estrutural é, pois, muitas vezes superior ao que se apresentou no passado. Ainda que por vezes alguma conjuntura histórica favorável ao crescimento da economia brasileira tenha feito parecer que nos afastávamos definitivamente de um passado identificado com o que era especificamente colonial, parece-nos claro que a reversão neocolonial reafirma a composição do passado arcaico com o presente moderno. A recente exacerbação do conflito entre capital e trabalho expressa de modo bastante claro os extremos a que a calibragem exercida pela burguesia brasileira sobre o excedente econômico pode chegar em tempos de neoliberalismo.

Assim, parece-nos que, a questão agrária e, pois, a reforma agrária, possuem um enorme potencial construtivo para a organização da economia brasileira. Embora atualmente não exista um êxodo rural como ocorreu em meados do século xx, a economia dos últimos quase quatro décadas não cresceu de forma sustentada nem vigorosa. É tanto necessário construir uma estrutura fundiária como também uma industrialização favoráveis à superação do subemprego estrutural que marca os países latino-americanos.

\section{LISTA DE REFERÊNCIAS}

Baltar, P. (2015). Crescimento da economia e mercado de trabalho no Brasil (Texto para discussão Núm. 2036). Recuperado de Instituto de Pesquisa Econômica Aplicada. Recuperado de http://hdl.handle.net/10419/121610

Cacciamali, M. C. (2007). (Pré-)Conceito sobre o setor informal, reflexões parciais embora instigantes. Revista Econômica, 9(1), 145-168. DOI: 10.22409/economica.9i1.p140

Carneiro, M. J. (2018). 'Rural' como categoria de análise. Ruris, 2(1), 9-38.

\footnotetext{
${ }^{37}$ Para Florestan Fernandes (1991), o “colonialismo não foi destruído até o fim e até o fundo” (p. 28). Em outro texto, o autor ainda salienta que o problema que o eixo da problemática latino-americana era a descolonização (1981, pp. 79-88).
} 
Castilho, A. L. (2012). Partido da terra: como os políticos conquistam o território brasileiro. São Paulo: Editora Contexto.

Coutinho, L. (1997). A especialização regressiva: Um balanço do desempenho industrial pósestabilização. Em J. P. R. Velloso (ed.), Brasil. Desafios de um país em transformação (pp. 81-106). Rio de Janeiro: J. Olympio.

Dedecca, C. (2012). Desigualdade, mas de qual falamos? Revista de Economia Política, 32(1), 5571.

Delgado, G. C. (2012). Do capital financeiro na agricultura à economia do agronegócio: mudanças cíclicas em meio século (1965-2012). Porto Alegre: Universidade Federal do Rio Grande do Sul.

Departamento Intersindical de Estudos e Estatícas (2016). Metodologia da Pesquisa Nacional da Cesta Básica de Alimentos. São Paulo: Autor.

Draibe, S. (1985). Rumos e metamorfoses. Um estudo sobre a constituição do Estado e as alternativas da industrialização no Brasil: 1930-1960. Rio de Janeiro: Paz e Terra.

Espósito, M. (2016). A importância do capital internacional nas transformações da estrutura produtiva brasileira: da industrialização à desindustrialização (Dissertação de mestrado). Universidade Estadual de Campinas, Campinas.

Fernandes, F. (1981). Poder e contrapoder na América Latina. Petrópolis: Zahar.

Fernandes, F. (1991). O PT em movimento: Contribuição ao $1^{\circ}$ Congresso do Partido dos Trabalhadores. São Paulo: Cortez /Autores Associados.

Fernandes, F. (2006). A revolução burguesa no Brasil: ensaio de interpretação sociológica. São Paulo: Globo.

Fernandes, F. (2008a). A integração do negro na sociedade de classes. São Paulo: Globo.

Fernandes, F. (2008b). Sociedade de classes e subdesenvolvimento. São Paulo: Global.

Fernandes, F. (2009). Capitalismo dependente e classes sociais na América Latina. São Paulo: Global.

Furtado, C. (1972). Análise do "modelo" brasileiro. Rio de Janeiro: Civilização Brasileira.

Furtado, C. (1980). O mito do desenvolvimento econômico. São Paulo: Nacional.

Furtado, C. (1982). A nova dependência: Dívida externa e monetarismo. Rio de Janeiro: Paz e Terra.

Hobsbawm, E. (1969). La marginalidad social en la historia de la industrialización europea. Revista Latinoamericana de Sociología, 5(1), 237-247.

Hobsbawm, E. J. (1995). Era dos extremos: o breve século xx 1914-1991 (2a ed). São Paulo: Companhia das Letras.

Hoffmann, H. (1980). Desemprego e subemprego no Brasil. São Paulo: Ática.

Instituto Brasileiro de Geografia e Estatística (2014). Censo Demográfico - 1980, 1991, 2000, 2010. Rio de Janeiro: Autor.

International Labour Office (1972). Employment, income and equality: A strategy for increasing productive employment in Kenya. Genebra: Autor.

Kowarick, L. (1975). Capitalismo e marginalidade na América Latina. Rio de Janeiro: Paz e Terra.

Marx, K. (2013). O capital: Crítica da economia política. São Paulo: Boitempo.

Mattos, F. A. M. de e Lima, S. da S. (2015). Apontamentos para o debate sobre o pleno emprego no Brasil. Economia e Sociedade, 24(2), 293-328. DOI: 10.1590/1982-3533.2015v24n2art3

Medeiros, C. (1998). Globalização e a inserção internacional diferenciada da Ásia e da América Latina. Em M. da C. Tavares e J. L. Fiori (eds.), Poder e dinheiro: uma economia política da globalização (6a. ed). Petrópolis: Editora Vozes.

Medeiros, C. (2015). Inserção externa, crescimento e padrões de consumo na economia brasileira. Brasília: Instituto de Pesquisa Econômica Aplicada. 
Nakatani, P. e Sabadini, M. (2002). Desestruturação e informalidade do mercado de trabalho no Brasil. Revista Venezolana de Análisis de Coyuntura, 8(2), 265-290.

Oliveira, A. (2003). Crítica à razão dualista: O ornitorrinco. São Paulo: Boitempo.

Oliveira, A. (2007). Modo capitalista de produção, agricultura e reforma agrária. São Paulo: Universidade de São Paulo/Labur Edições.

Pinto, A. (1976). Heterogeneidade estrutural e modelo de desenvolvimento recente. Em J. Serra (ed.), América Latina: ensaios de interpretação econômica (pp. 44-82). Rio de Janeiro: Paz e Terra.

Portugal Jr., J. G. (1998). Economia regional e os problemas do emprego. São Paulo: Fundap.

Portugal Jr., J. G. (2012). Padrões de heterogeneidade estrutural no Brasil (Tese de doutorado). Campinas, Universidade Estadual de Campinas.

Prado Jr., C. (1987). A revolução brasileira. São Paulo: Brasiliense.

Prado Jr., C. (2012). História econômica do Brasil. São Paulo: Brasiliense.

Robinson, J. (1937). Disguised unemployment. Em Essays in the theory of employment (pp. 60-74). Oxford: Basil Blackwell.

Rodríguez, O. (1985). Agricultura, subempleo y distribución del ingreso: Notas del caso brasileño. Economía de América Latina, 13, 63-77.

Sampaio Jr., P. A. (2007). Globalização e reversão neocolonial: O impasse brasileiro. Em G. Hoyos (ed.), Filosofía y teorías políticas entre la crítica y la utopía. Buenos Aires: CLACSO.

Souza, P. R. (1980). Emprego, salário e pobreza. São Paulo: Hucitec/Fundação de Desenvolvimento da Unicamp.

Souza, P. R. (1999). Salário e emprego em economias atrasadas. Campinas: Universidade Estadual de Campinas.

Suzigan, W. (1992). A indústria brasileira após uma década de estagnação: Questões para política industrial. Economia e Sociedade, 1, 89-109.

Szmrecsányi, T. (1982). Análise das políticas para o setor agropecuário. Em L. G. de M. Belluzzo e R. Coutinho (eds.), Desenvolvimento capitalista no Brasil: ensaios sobre a crise (pp. 255-274). Campinas: Universidade Estadual de Campinas.

Tavares, M. C. (1981). Problemas de industrialización avanzada en capitalismos tardíos y periféricos. Economía de América Latina, 6, 21-42.

Tokman, V. (1978). Distribución del ingreso, pobreza y empleo en áreas urbanas. El Trimestre Económico, 45(1), 737-766.

Tokman, V. y Souza, P. R. (1976). El sector informal urbano en América Latina. Revista Internacional del Trabajo, 94(3), 385-397.

Zullo, G. J. D. (2014). A questão salarial revisitada: Exército industrial de reserva e heterogeneidade estrutural (Dissertação de mestrado). Universidade Estadual de Campinas, Campinas.

Zullo, G. J. D. (2017). Interpretações da estrutura ocupacional na América Latina: o debate marxista e a heterogeneidade estrutural. História Econômica \& História de Empresas, 20(1), 209241. DOI: 10.29182/hehe.v20i1.442 